\title{
THE CORRELATION OF WATER WITH SETTLEMENT AND TRANSPORTATION NETWORK: A CASE STUDY OF TURKEY
}

\author{
Ömer ATABEYOĞLU \\ Department of Landscape Architecture, Faculty of Agrigulture, Ordu University in Ordu, Turkey
}

Submitted 13 May 2015; accepted 13 Apr. 2016

\begin{abstract}
Cities, with their ancient history, are living formations that develop and change constantly. Although there are several economical, safety and transportation reasons for their foundation purposes and for the locations where cities founded, geographical conditions also significantly affect these reasons. One of the most important elements determining the area where the cities have been founded is the water. This article examined how the geographical water resources affect the humankind settlements and the transportation network. The relationships, similarities and differences between transport and water networks were revealed using fractal analysis method. The effect of water on the location of living areas was also determined by using the bufferzone method. Swot analysis was made for evaluated to affects of the roads on ecosystem and landscape. The study was carried out on the base of 81 provinces in Turkey. The roads in the country that was netted with dense transportation networks were passed through considering the geographic elements. Rivers, lakes and seas are important factors in determining the transit routes of the roads. The water elements use the routes for which geographic conditions are the most suitable and this serves as a guide for the transport network. Additionally, provincial and district centers have also been established to be particularly close to the water element due to its landscape and economic factors, the appropriate geographic and climatic conditions.
\end{abstract}

Keywords: landscape management, environmental sustainability, fractal analysis, river network, road network.

\section{Introduction}

Water is one of the crucial determinant and formative element in all aspects of life. Humans, as they cannot survive without water, the very foundation of their life, have always inhabited the places that are close to water and water sources and easily accessible. They have chosen and designed the settlement places particularly in accordance with this. With the contribution of other geological and natural factors, they have provided with the formation of our today's world, cities, residences and lifestyles.

Together with other geological and natural factors, water factor is the most effective on determining itineraries, forming routes and the arteries that connects our habitats. The transportation network was mostly followed the natural pathway of the closest sea, surrounded the lakes and relied on the guideline of the rivers.

"It was determined that most of ancient people lived on the beaches and coasts of the dried and drying lakes, alluvial plains and cones of deposit which provided easy access to their water need. The tumulus, as their surroundings have fertile soils, were very convenient areas to meet the basic needs of the first age people. They made their own living by hunting wild animals in swampy areas and in lands near lakes, they also occupied with a small-scale agriculture on those fertile plains" (Topur 2009).

Roads and rivers are the important corridors for urban expansion too. Before the invention of automobiles, cities developed along river sand coastlines because waterborne transportation was so important. Rivers are important natural corridors (Tian, Wu 2015). Old roads are curvy and follow the landforms, whereas the modern roads often ignore landforms and cross the county in straight lines (Seppala 1999). Interaction between stream and transportation networks is more complex, with the roads paralleling the streams in some locations. In small valleys the transportation network follows the trunk stream more closely (Blanton, Marcus 2009).

According to Liu et al. (2014), transportation infrastructures built in line with a city's expansion, particularly road networks, cause both direct and indirect losses of habitat, which, in turn, influence the abundance and distribution of plant and animal species (Geneletti 2003; Eigenbrod et al. 2007).

Corresponding author: Ömer Atabeyoğlu

E-mail: atabey6@hotmail.com 
Recent large-scale studies have often explored the relationship between road networks and landscape pattern by applying road density and road effect as the parameters of road networks' impact (Hawbaker, Radeloff 2004; Liu et al. 2008; Fu et al. 2010; Patarasuk 2013; Jenelius, Mattsson 2015).

The rivers that compatible with topography are the most compatible spaces. The ways circulate circle of lake, continue down the parallel of river or sea. All time, water is evidence of civilization and is accepted as guide and route. Waterfronts have scenery, optimum climate, fertile soil as agriculture and source as needs. The aim of this study to reveal in the cities of Turkey to the physical effect of the rivers, lakes and seas on determined of the route and plan for road, and to similarity between road network and hydrology network, and to relation between locations of current settlements and water elements.

Aim of the study sea, lake and rivers put forth their direct and indirect effects on transportation function. Running and still waters effect on environment at both urban and suburban. The effect of this element on the one of the human made functions puts forth to relationship between nature and human. The study emphasizes important of natural factors to designs and plans in our urban and suburban areas. Another aim expresses that the works made according to the natural factors important for succeed in terms of function and aesthetic. At the same time it indicates that the human follows nature knowingly and unknowingly in the developments.

\section{Methodology}

\subsection{General description of the study area}

The study material includes stagnant and running water network, transportation network, provincial and district centers found in Turkey. Turkey do have an area, including lakes, $783.577 \mathrm{~km}^{2}$. The length of Turkey's land border is $2.949 \mathrm{~km}$, with its coastal length is 7.816 kilometers (DSI 2016).

\subsection{Preparation and analyzing}

The method of the study constitutes the evaluation of the maps prepared based on Photoshop 9.0 and ArcGIS 9.1 programs. All maps are based on the physical and political maps obtained from website of the General Command of Mapping (HGK 2013a; HGK 2013b). All flowing water routes, stagnant waters' shorelines, the centers of province and district were obtained from those maps. The main reasons for the preference of those maps are that they are reliable and scaled military maps with high standards. Harfa5.3 program was used to make fractal analyze of all maps. To evaluate the fractal analysis method, Kaya (2003), Atabeyoğlu et al. (2012) is followed.

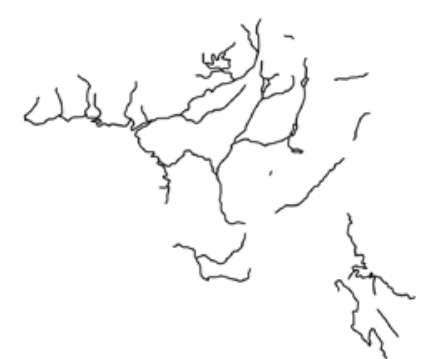

Hydrological network map that has
prepared for fractal analysis

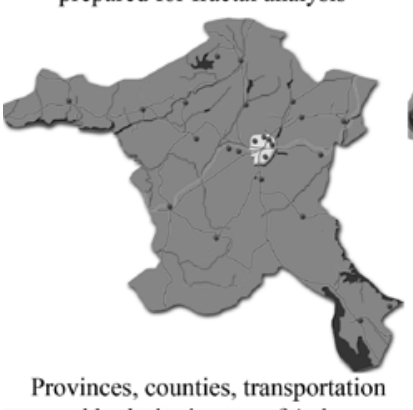

and hydrologic map of Ankara

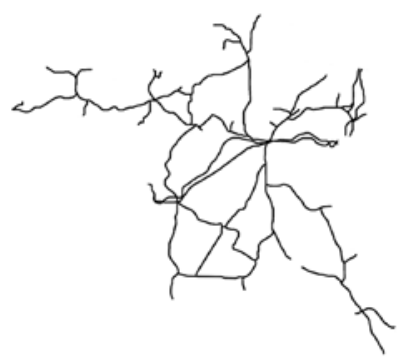

Transportation network map that has prepared for fractal analysis

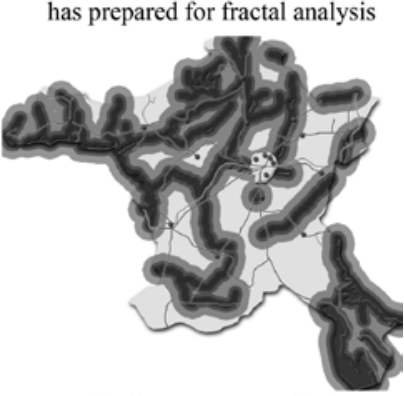

Buffer zone map of Ankara
Fig. 1. The map of hydrology, road, province and county centers, Ankara city case

All 81 provinces were taken under evaluation in this study. For each province separately, black-and-white maps showing the transport network and hydrological network were prepared (Fig. 1). Fractal analysis of all maps by using Harfa program was made and fractal analysis values obtained for each map were used to compare two maps of the same province.

All 81 provinces in Turkey have been mapped on the basis of their hydrological transport network (rivers, lakes and seas) and transport network. Fractal analysis of 162 maps of 81 cities have been made with the use of Harfa software and their fractal values have been determined. The higher fractal value reveals the complexity, homogenous dispersion and the density of transport or hydrologic network. On the other hand, its low value expresses simplicity, heterogeneity, and low density. Similarity of the fractal values of both maps of the same city also indicates that they have similarities in terms of their characteristics. As the values get closer to each other, the relationship between the maps increases.

After the determination of fractal values, the fractal values obtained from the maps related with both water elements and transport were grouped in order to compare with each other and to reveal the similarities and the differences. For this grouping, the difference between the second highest and lowest fractal values was divided by 5 . The obtained value was added to the second lowest value so that 5 groups were formed and the fractal values were classified under these 5 groups (Table 1). Thus, 5 similarity groups were formed and then the similarities 
of the maps containing transport network and water network of the same province was evaluated. The evaluated method was adapted than Atabeyoğlu and Bulut (2007) and Atabeyoğlu (2004).

Table 1. Fractal value groups

\begin{tabular}{cc}
\hline \multicolumn{2}{c}{ Hydrology + Road } \\
\hline Fractal value & Explanation \\
\hline$\leq 1.169$ & 1 \\
\hline $1.170-1.292$ & 2 \\
\hline $1.293-1.415$ & 3 \\
\hline $1.416-1.538$ & 4 \\
\hline $1.539 \leq$ & 5 \\
\hline
\end{tabular}

After grouping the fractal values, water and transport fractal values of the same province were compared with each other and the difference between fractal groups was determined. Based upon the series of fractal values, fractal values of the cities were grouped into 5 and compared with each other after that the differences between the maps were evaluated, resulting in the differences ranging from 0 to 4 . The value of " 0 " demonstrates that there is no relative difference between the 2 maps of the same city and " 4 " is the value demonstrating that there is no relative similarity between the two maps. It can be said that there is a parallelism between the hydrological network and the transport network of the cities defined with 0 , the transport network follows the water network with a strong correlation between these two and the water elements are dominant and determinative on transportation route. On the other hand, the case for the cities defined with " 4 " refers exactly the opposite. Furthermore, percent similarity ratios related to these difference were expressed as percent value of the two values and added to the table.

Buffer Zone Method was used to determine the relationship between the places where the cities and counties were established and the water elements. Using the maps obtained from the site of General Command of Mapping, based on the centers of cities and counties, 2,5, 5 and $10 \mathrm{~m}$ zones were constituted in the circle of water elements and the number of the cities and counties placed in and out the zones were determined. Thus, in choosing the places for city and county centers, the effect of closeness to water was tried to put forward. The relationships were visualized by using the maps related to the values of fractal analysis and buffer zone analysis.

\subsection{Statistical analysis}

Statistical analysis was conducted to determine the relationship of water with road and settlement. Statistical analysis was carried out to strengthen the evaluation of relationships of water network with the road network and with city and district settlements. Accordingly, coastal and non-coastal provinces were classified and the relationships and the interactions between road and water networks in both provincial and country bases were determined. The data of fractal values were displayed as mean \pm standard error of the mean (SEM), standard deviation. The assumptions of data normality, which are prerequisite for correlation analysis, were tested with the Kolmogorov-Smirnov normality test. The Pearson correlation coefficient was calculated to assess the concordance fractal values between water and road. Pearson chi-square test were performed for the locations of the counties (have/haven't coast to sea and lake) to assess significant differences among distance to water elements $(2.5 \mathrm{~km}, 5 \mathrm{~km}, 10 \mathrm{~km}, 10 \mathrm{~km}<)$. Likelihood/Fisher's exact chi-square tests were used when cell sizes were less than 5 . The alpha level was set at 5\%. All calculations were performed with SPSS 23 statistical software.

Finally, SWOT analysis was made. SWOT analysis is a good method for evaluated positive, negative, true and wrong sides. It was evaluated strengths, weaknesses, opportunities and threats on rivers, lakes and sea of roads follow shores with SWOT.

\section{Results}

Turkey is a geographic region with high density of water elements. Several large and small rivers, lakes, dams and the sea surround the territory of Turkey like a network (Fig. 2). These natural elements are often found in both urban and rural areas in every province. Turkey also has a very rugged geography. The roads in the country that was netted with dense transportation networks were passed through considering the geographic elements (Fig. 3). In this context, residential and transport network should be related with geographic elements and flowing and stagnant waters. Fractal analysis was used to reveal and objectify these relations.

Information concerning the maps of hydrological and transport networks belonging to the provinces was converted to numerical expressions and compared. For this reason, the relationships among fractal values with their similarities and differences were considered. The fractal similarity ratio represents the similarity relation of the provincial fractal values as percentage. A $100 \%$ resemblance ratio indicates that the classification groups of fractal values are the same. Among the cities, 12 of them are located on the coastal area, but the other 12 in the inland. The number of cities with seashore and a resemblance ratio over $50 \%$ is 25 , while the number of non-coastal is 42 (Table 2, Fig. 4).

Water is a crucial factor for all settlements in terms of strategic, economic, visual, and climatic aspects. The relation of hydrology network with settlement is important 


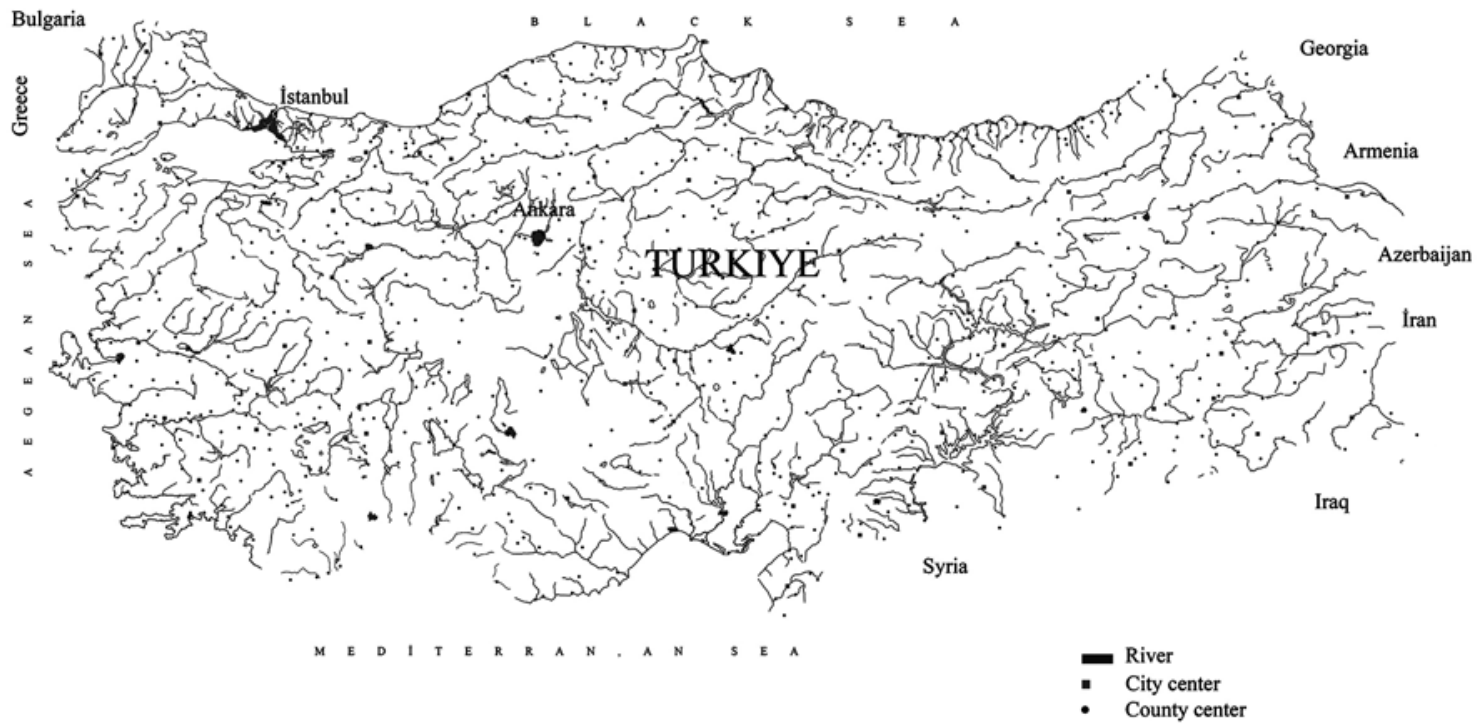

Fig. 2. Map of hydrology network

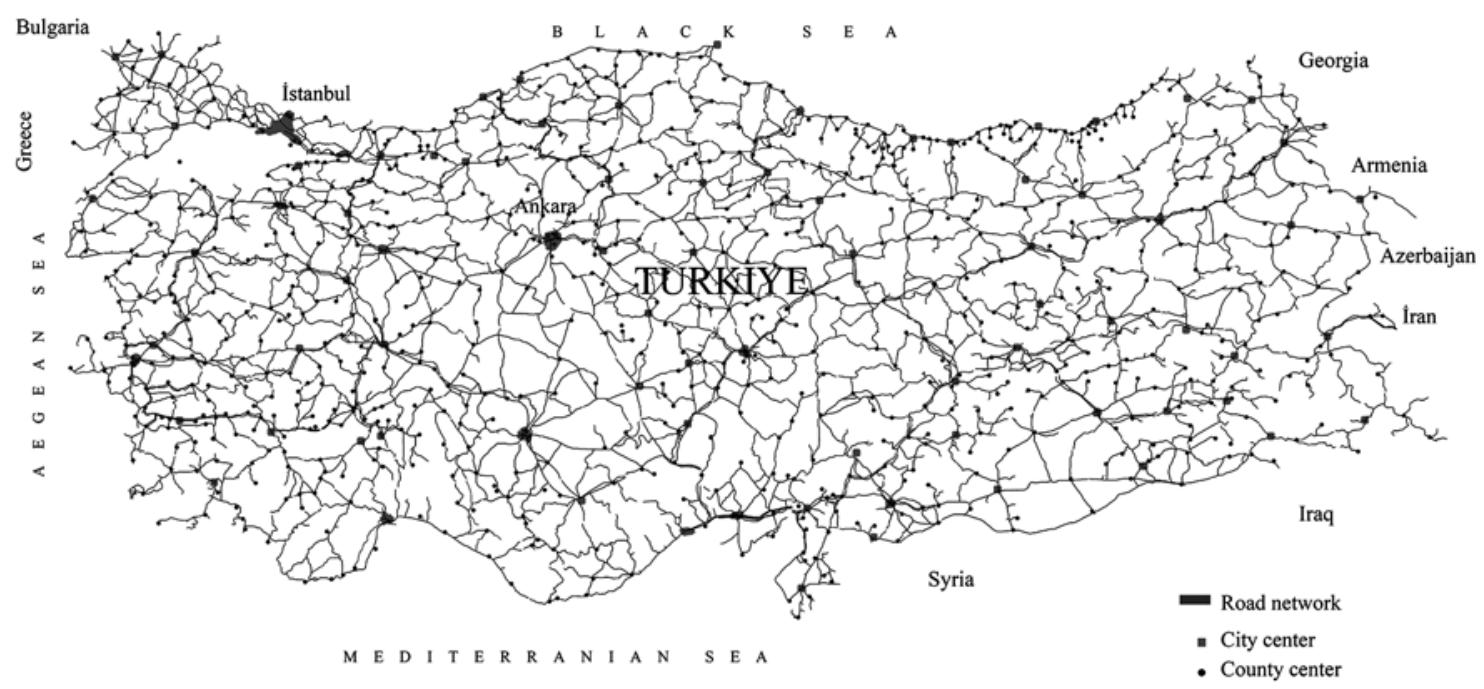

Fig. 3. Map of road network

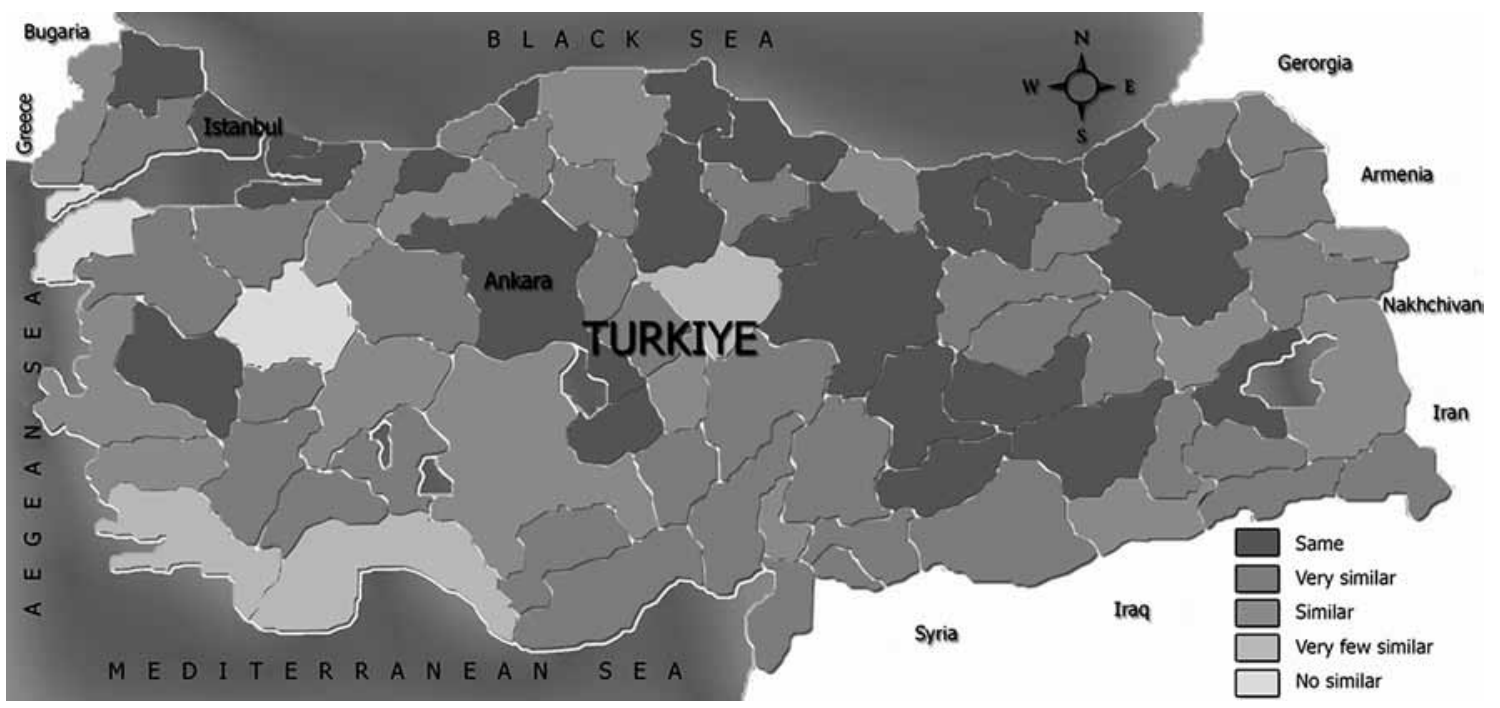

Fig. 4. Range of the cities according to the groups of fractal value 
Table 2. Fractal values, values groups and similarity of the cities

\begin{tabular}{|c|c|c|c|c|c|c|c|}
\hline Provinces & $\begin{array}{l}\text { Fractal value } \\
\text { (water-road) }\end{array}$ & $\begin{array}{c}\text { Fractal value } \\
\text { group } \\
\text { (water-road) }\end{array}$ & $\begin{array}{c}\text { Fractal } \\
\text { similarity rate } \\
(\%)\end{array}$ & Provinces & $\begin{array}{l}\text { Fractal value } \\
\text { (water-road) }\end{array}$ & $\begin{array}{c}\text { Fractal value } \\
\text { group } \\
\text { (water-road) }\end{array}$ & $\begin{array}{c}\text { Fractal } \\
\text { similarity rate } \\
(\%)\end{array}$ \\
\hline \multicolumn{8}{|c|}{ The cities haven't coast to sea and lake } \\
\hline Adiyaman & $1,338-1,311$ & $3-3$ & 100 & Bayburt & $1,080-1,256$ & $1-2$ & 50 \\
\hline Afyon & $1,179-1.501$ & $2-4$ & 50 & Karaman & $1,112-1,274$ & $1-2$ & 50 \\
\hline Ağri & $1,233-1,152$ & $2-1$ & 50 & Kirikkale & $1,098-1,255$ & $1-2$ & 50 \\
\hline Amasya & $1,141-1,276$ & $1-2$ & 50 & Batman & $1,154-1,292$ & $1-2$ & 50 \\
\hline Ankara & $1,526-1,485$ & $4-4$ & 100 & Şirnak & $1,105-1,211$ & $1-2$ & 50 \\
\hline Bilecik & $1,093-1,326$ & $1-3$ & 33 & Ardahan & $1,148-1,197$ & $1-2$ & 50 \\
\hline Bingöl & $1,476-1,303$ & $4-3$ & 75 & Iğdir & $1,301-1,123$ & $3-1$ & 33 \\
\hline Bolu & $1,122-1,312$ & $1-3$ & 33 & Karabük & $1,059-1,282$ & $1-2$ & 50 \\
\hline Burdur & $1,240-1,213$ & $1-2$ & 50 & Kilis & $1.025-1,248$ & $1-2$ & 50 \\
\hline Çankiri & $1,080-1,262$ & $1-2$ & 50 & Osmaniye & $1,061-1,340$ & $1-3$ & 33 \\
\hline Çorum & $1,135-1,000$ & $1-1$ & 100 & \multicolumn{4}{|c|}{ The cities have coast to sea and lake } \\
\hline Denizli & $1,166-1,251$ & $1-2$ & 50 & Adana & $1,613-1,482$ & $5-4$ & 80 \\
\hline Diyarbakir & $1,221-1,263$ & $2-2$ & 100 & Antalya & $1,090-1,418$ & $1-4$ & 25 \\
\hline Elaziğ & $1,341-1,403$ & $3-3$ & 100 & Artvin & $1,156-1,271$ & $1-2$ & 50 \\
\hline Erzincan & $1,207-1,260$ & $1-2$ & 50 & Aydin & $1,273-1,332$ & $1-3$ & 50 \\
\hline Erzurum & $1,789-1,625$ & $5-5$ & 100 & Balikesir & $1,408-1,510$ & $3-4$ & 75 \\
\hline Eskişehir & $1,149-1.277$ & $1-2$ & 50 & Bitlis & $1,173-1,254$ & $2-2$ & 100 \\
\hline Gaziantep & $1,507-1,372$ & $4-3$ & 75 & Bursa & $1,534-1,580$ & $4-5$ & 80 \\
\hline Gümüşhane & $1,000-1,180$ & $1-1$ & 100 & Çanakkale & $1,000-1,591$ & $1-5$ & 20 \\
\hline Hakkari & $1.103-1.176$ & $1-2$ & 50 & Edirne & $1,303-1,547$ & $3-5$ & 60 \\
\hline Isparta & $1,218-1,294$ & $2-3$ & 67 & Giresun & $1,258-1,237$ & $2-2$ & 100 \\
\hline Kars & $1,235-1,307$ & $2-3$ & 67 & Hatay & $1.191-1,307$ & $2-3$ & 67 \\
\hline Kayseri & $1,371-1,282$ & $3-2$ & 67 & Içel & $1,354-1.472$ & $3-4$ & 75 \\
\hline Kirşehir & $1,238-1,352$ & $2-3$ & 67 & Istanbul & $1,517-1,475$ & $4-4$ & 100 \\
\hline Konya & 1,399-1,661 & $3-5$ & 60 & Izmir & $1,414-1,000$ & $3-1$ & 33 \\
\hline Kütahya & $1,000-1,585$ & $1-5$ & 20 & Kastamonu & $1,359-1,653$ & $3-5$ & 60 \\
\hline Malatya & 1,509-1.509 & $4-4$ & 100 & Kirklareli & $1,485-1,423$ & $4-4$ & 100 \\
\hline Manisa & $1,532-1,521$ & $4-4$ & 100 & Kocaeli & $1,306-1,415$ & $3-3$ & 100 \\
\hline K.maraş & $1,149-1,291$ & $1-2$ & 50 & Muğla & $1,702-1,253$ & $5-2$ & 40 \\
\hline Mardin & $1,047-1,330$ & $1-3$ & 33 & Ordu & $1,234-1,469$ & $2-4$ & 50 \\
\hline Muş & $1,150-1,294$ & $1-3$ & 33 & Rize & $1,217-1,288$ & $2-2$ & 100 \\
\hline Nevşehir & $1,107-1,315$ & $1-3$ & 33 & Sakarya & $1,216-1,299$ & $2-3$ & 67 \\
\hline Niğde & $1,165-1,268$ & $1-2$ & 50 & Samsun & $1,310-1,368$ & $3-3$ & 100 \\
\hline Siirt & $1,137-1,222$ & $1-2$ & 50 & Sinop & $1,331-1,322$ & $3-3$ & 100 \\
\hline Sivas & $1,165-1,000$ & $1-1$ & 100 & Tekirdağ & $1,317-1,513$ & $3-4$ & 75 \\
\hline Tokat & $1,344-1,394$ & $3-3$ & 100 & Trabzon & $1,281-1,259$ & $2-2$ & 100 \\
\hline Tunceli & $1,212-1,328$ & $2-3$ & 67 & Van & $1,409-1,000$ & $3-1$ & 33 \\
\hline Şanliurfa & $1,292-1,000$ & $2-1$ & 50 & Zonguldak & $1,240-1,337$ & $2-3$ & 67 \\
\hline Uşak & $1,179-1,347$ & $2-3$ & 67 & Bartin & $1,182-1,273$ & $2-2$ & 100 \\
\hline Yozgat & $1,247-1,645$ & $2-5$ & 40 & Yalova & $1,232-1,243$ & $2-2$ & 100 \\
\hline Aksaray & $1,182-1,223$ & $2-2$ & 100 & Düzce & $1,209-1,235$ & $2-2$ & 100 \\
\hline
\end{tabular}


as well as with the transport network. The relationship between the hydrological network with the settlements was evaluated on the basis of provincial and district locations (Fig. 5). The evaluation was made on the basis of 970 districts of Turkey's 81 cities (E-Interior 2016). The coastal and non-coastal cities to the large water elements and their districts are evaluated separately. According to this evaluation, there are 28 coastal cities with their 411 districts, and 53 non-coastal cities with their 559 districts. In general, a total of 70 provinces ( 42 coastal and 28 noncoastal) was located within the area that is $10 \mathrm{~km}$ away from existing water elements (Table 2, Fig. 5).

According to fractal values, in terms of water elements, 32 cities have very low fractal value of $40 \%$, and 3 cities have a very high value of $4 \%$. When evaluated in terms of road network, 8 cities have very low value of $10 \%$, and 8 cities have very high fractal value of $10 \%$. The distribution of fractal values concerning water and transport networks indicates that, though it seems the of opposite the distribution related to the intervals of the highest and

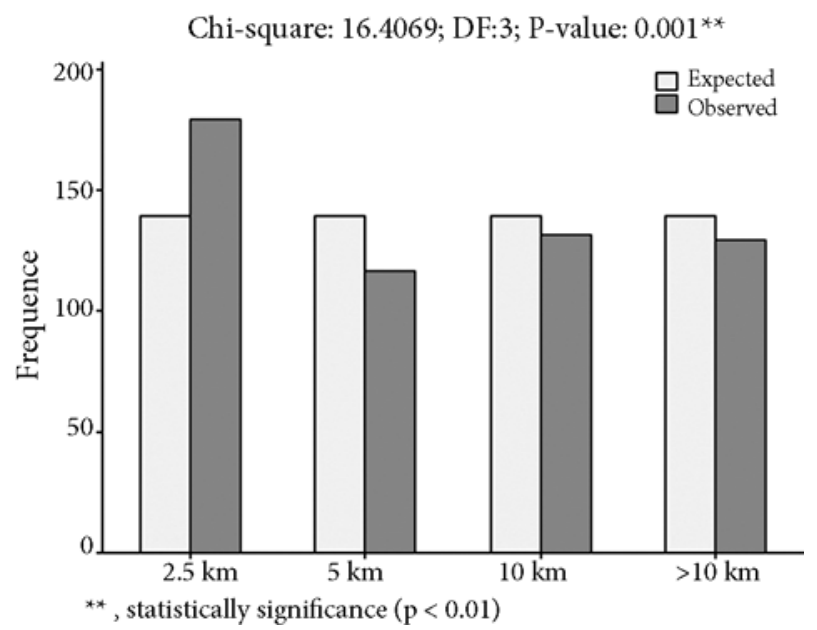

a)

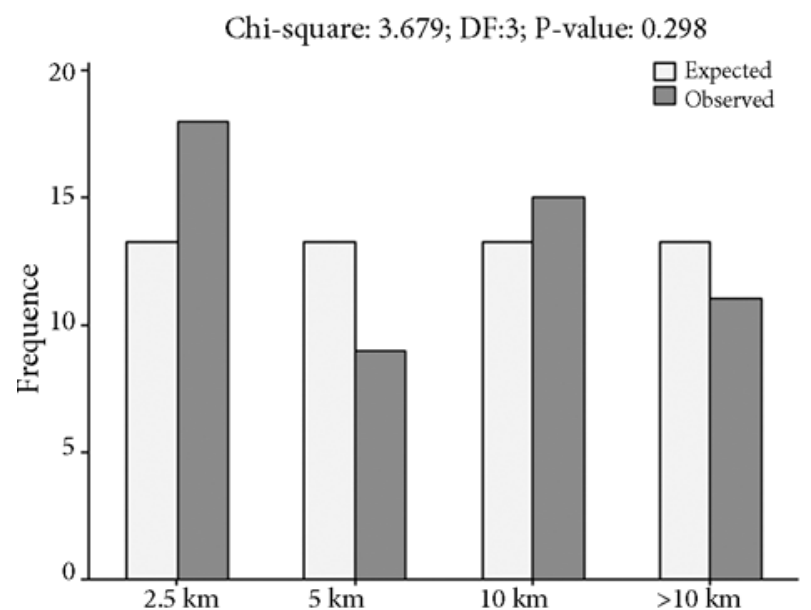

c)

Fig. 5. Number of provinces and counties according to distances: a) number of counties with no coast to big water masses to distances; b) number of counties with coast to big water masses to distances; c) number of provinces with no coast to big water masses to distances; d) number of provinces with coast to big water masses to distances
Table 3. The rate of the groups of fractal similarity

\begin{tabular}{lcccc}
\hline & \multicolumn{2}{c}{ Water network } & \multicolumn{2}{c}{ Road network } \\
\cline { 2 - 5 } & Frequency & Percent & Frequency & Percent \\
\hline Very low & 32 & 39,5 & 8 & 9,9 \\
\hline Low & 22 & 27,2 & 30 & 37,0 \\
\hline Middle & 16 & 19,8 & 23 & 28,4 \\
\hline High & 8 & 9,9 & 12 & 14,8 \\
\hline Very high & 3 & 3,7 & 8 & 9,9 \\
\hline Total & 81 & 100,0 & 81 & 100,0 \\
\hline
\end{tabular}

lowest values, there is a parallelism between them when low and high values included (Table 3 ).

The number of provinces and counties was determined from the bufferzone maps prepared for determining provinces and counties settlements within the distances of 2.5, 5 and $10 \mathrm{~km}$ from the water elements. In total, $79 \%$ of the counties is located in an area of $10 \mathrm{~km}$ (Table 4).

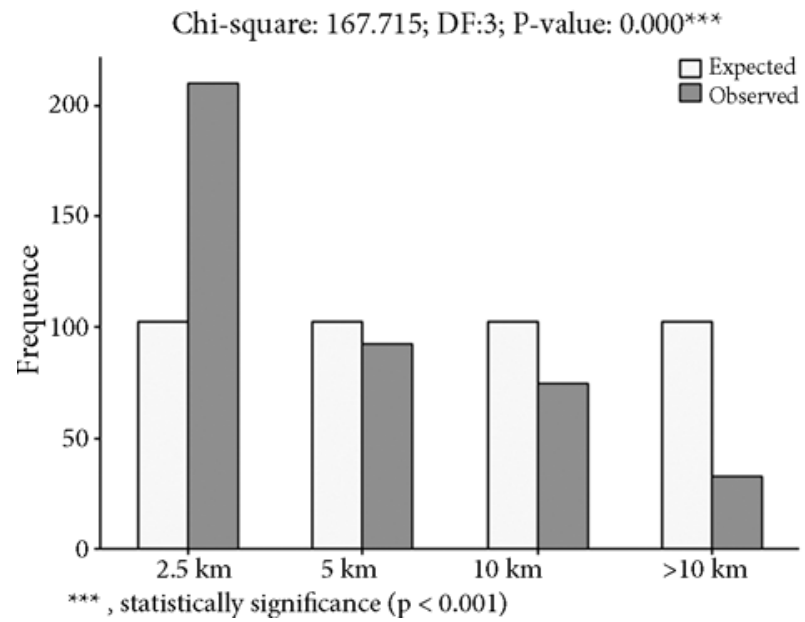

b)

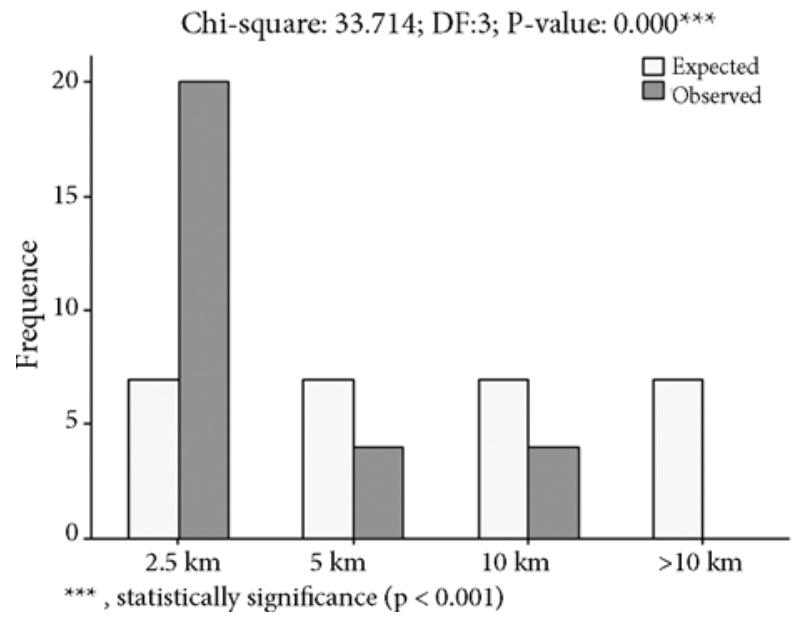

d) 
Table 4. Distribution of counties and provinces according to distances

\begin{tabular}{|c|c|c|c|c|c|}
\hline \multirow{4}{*}{ Counties } & & $2.5 \mathrm{~km}$ & $5 \mathrm{~km}$ & $10 \mathrm{~km}$ & $10 \mathrm{~km}<$ \\
\hline & The coastal cities to the large water elements & $\% 19$ & $\% 9.9$ & $\% 7.6$ & $\% 3.5$ \\
\hline & The non-coastal cities to the large water elements & $\% 17.5$ & $\% 11.6$ & $\% 13.1$ & $\% 13$ \\
\hline & Total & $\% 36.6$ & $\% 21.5$ & $\% 20.8$ & $\% 16.6$ \\
\hline \multirow{3}{*}{ Provinces } & The non-coastal cities to the large water elements & $\% 22.2$ & $\% 11.1$ & $\% 18.5$ & $\% 13.5$ \\
\hline & The coastal cities to the large water elements & $\% 24.6$ & $\% 4.9$ & $\% 4.9$ & $\% 0$ \\
\hline & Total & $\% 46.8$ & $\% 16$ & $\% 23.4$ & $\% 13.5$ \\
\hline
\end{tabular}

Table 5. Pearson correlation coefficients of fractal value between water and road

\begin{tabular}{|c|c|c|c|c|c|c|}
\hline Counties & Region & $n$ & Mean \pm SEM & $\begin{array}{l}\text { Standard } \\
\text { deviation }\end{array}$ & $\begin{array}{c}\text { Correlation } \\
\text { coefficient }\end{array}$ & P-Value \\
\hline \multirow{2}{*}{ The cities have coast to sea and lake } & Road & 30 & $1.361 \pm 0.028$ & 0.155 & \multirow{2}{*}{0.055} & \multirow{2}{*}{$0.771^{\mathrm{NS}}$} \\
\hline & Water & 30 & $1.311 \pm 0.028$ & 0.152 & & \\
\hline \multirow{2}{*}{ The cities haven't coast to sea and lake } & Road & 51 & $1.306 \pm 0.020$ & 0.145 & \multirow{2}{*}{0.447} & \multirow{2}{*}{$0.001^{* *}$} \\
\hline & Water & 51 & $1.217 \pm 0.022$ & 0.159 & & \\
\hline \multirow[t]{2}{*}{ All of the cities } & Road & 81 & $1.326 \pm 0.017$ & 0.150 & \multirow[t]{2}{*}{0.334} & \multirow[t]{2}{*}{$0.002^{* *}$} \\
\hline & Water & 81 & $1.252 \pm 0.018$ & 0.162 & & \\
\hline
\end{tabular}

* SEM, Standard error of mean; ${ }^{* *}$ statistically significant $(p<0.01)$; ${ }^{* *}$ statistically significant $(p<0.001)$; NS, statistically not significant $(p>0.05)$

In the assessment of urban settlements, among the non-coastal provinces to large water masses 18 cities are located in 2,5 km, 9 cities in $5 \mathrm{~km}, 15$ cities in $10 \mathrm{~km}$ and 11 cities in $+10 \mathrm{~km}$ away from existing water sources. As for the cities having shores to the large water masses, 20 city centers are located in 2,5 km, 4 in $5 \mathrm{~km}$, and 4 in $10 \mathrm{~km}$ distance to water element.

Based on fractal analysis comparisons, substantial similarities between hydrological and transportation networks of the provinces have been identified. Between the two maps of the cities, considering the percentage values, high similarity rate is $75.4 \%$ with 61 cities, little similarity rate is $18.5 \%$ with 15 cities and very little or dissimilarity rate is $6.1 \%$ with 5 cities. The average percentage of similarity is $74 \%$ in reference with the fractal values of coastal cities, while it is $62 \%$ in the noncoastal ones. The fractal similarity percentage across the country is $66 \%$. According to this result, there is a high parallelism between hydrological and transport networks in Turkey.

Though similarity includes the majority of the provinces, when it is compared with information regarding the geographical location of the provinces showing high rate of similarity, it corresponds to varying topography and highlands. Even though they are mostly in high altitudes, it is observed that the provinces showing low or no similarities, have been placed calm topographic, and lower mobility areas. The transport network mostly comply with existing valleys, and the water routes in areas with high geographical restrictions, and the diverse topographic changes, while in a relatively quiet topography there is no similar compliances due to better geographical conditions (Fig. 6).

According to Pearson correlation tests (Table 5). The cities identified as the same" or "very similar" are approximately $75 \%$ of the country's whole provinces. The total percentage of the cities within the groups of little similarity, no similarity or very low similarity cities percentages remained at $25 \%$ (Table 6).

For the cities have coast to water; mean of road network is $1.361 \pm 0.028$, mean of water network is $1.311 \pm 0.028$. The coefficient of correlation between water and road networks is 0.055 , but it is not statistically significant $(p>0.05)$. For the cities haven't coast to water; mean of road network is $1.306 \pm 0.020$, mean of water

Table 6. Distribution of provinces to groups of fractal values

\begin{tabular}{ccc}
\hline $\begin{array}{c}\text { Groups of fractal } \\
\text { values }\end{array}$ & $\begin{array}{c}\text { Number of } \\
\text { provinces }\end{array}$ & Percentage \\
\hline 0 - same & 24 & $\% 29,6$ \\
\hline 1 - very similar & 37 & $\% 45,8$ \\
\hline 2 - little similar & 15 & $\% 18,5$ \\
\hline $3-$ very little similar & 3 & $\% 3,7$ \\
\hline $4-$ no similar & 2 & $\% 2,4$ \\
\hline
\end{tabular}


network is $1.217 \pm 0.022$. The coefficient of correlation between water and road networks is 0.447 , and it is statistically significant $(p<0.01)$. If the fractal value of road network increases, the fractal value of water network increases at the rate of $44.7 \%$. For the all of the cities; mean of road network is $1.326 \pm 0.017$, mean of water network is $1.252 \pm 0.018$. The coefficient of correlation between water and road networks is 0.334 , and it is statistically significant $(p<0.01)$.

Together with obtained results, SWOT analysis was made for evaluated to affects of the roads that follow river, lake and sea.

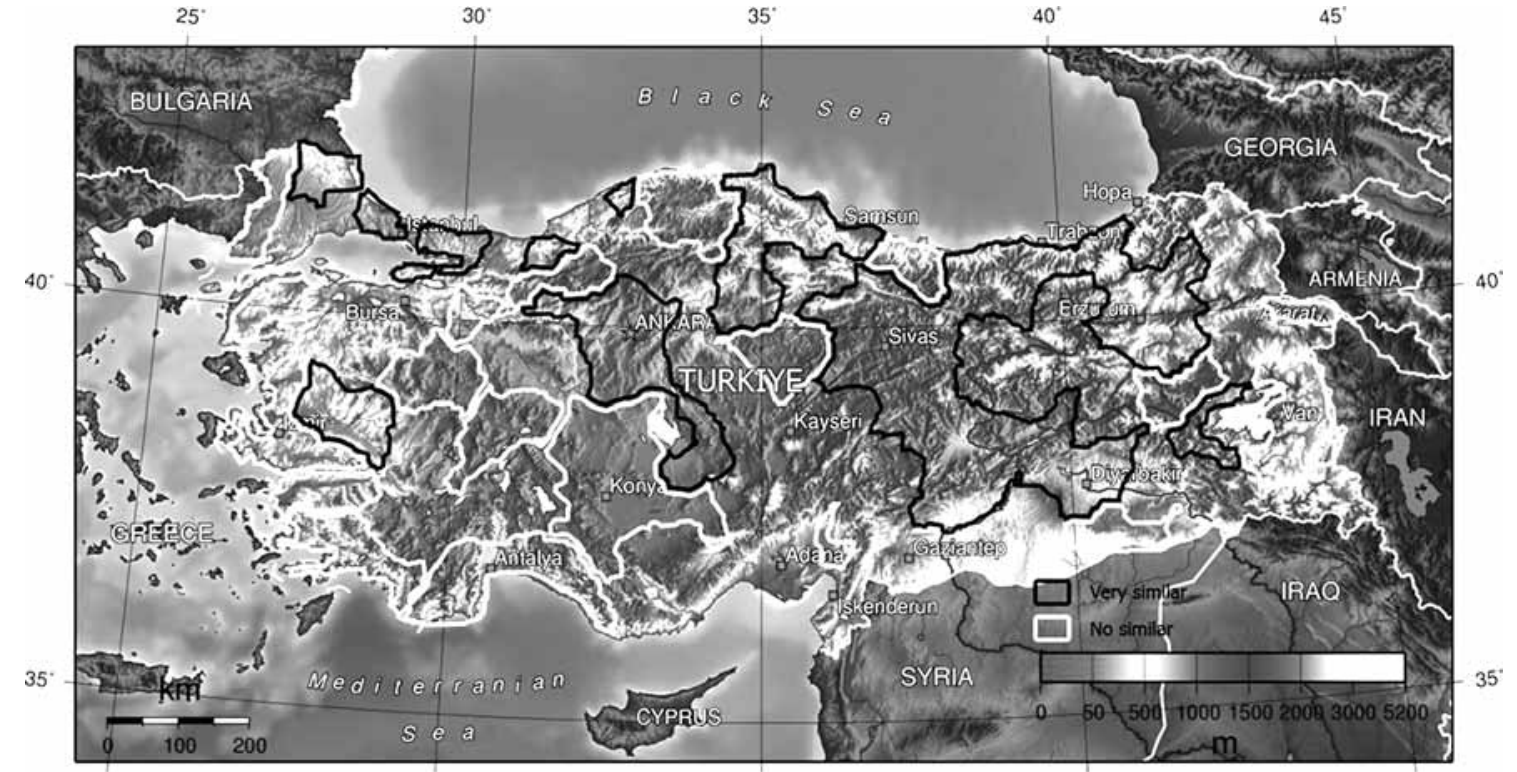

Fig. 6. Topographic map for the similarity of hydrology and road networks

\begin{tabular}{|c|c|}
\hline Strengths & Weaknesses \\
\hline $\begin{array}{l}\text { - Aesthetic value and scenery of shores and river lines are high. } \\
\text { - Travel enjoyment is high. } \\
\text { - These roads require minimum amount of excavation and } \\
\text { filling, because these roads, e. g. water pass form in optimal } \\
\text { land conditions. } \\
\text { - The roads following the water are economic, as this road } \\
\text { doesn't need excavation-filling and tunnels. } \\
\text { - Transportation to city near the water is easy. } \\
\text { - These roads have connection with water transportation. } \\
\text { - Vegetable material is rich, intensive and various. } \\
\text { - These roads have transportation safety. } \\
\text { - It is the shortest route to transportation. } \\
\text { - It is in harmony with nature. } \\
\text { - It is one of the most harmless methods to nature, as } \\
\text { engineering activities are almost not needed. } \\
\text { - Extreme weather does not influence the roads because they are } \\
\text { in low altitude } \\
\text { - It is economic, easy to transport }\end{array}$ & $\begin{array}{l}\text { - The roads weaken aesthetic value of water shores and divide } \\
\text { scenery. } \\
\text { - The roads have too much of meanders. } \\
\text { - River corridors have intensive air movements. } \\
\text { - It is necessary to bridge in order to pass rivers. } \\
\text { - Agricultural estates and fertile lands are divided by roads. } \\
\text { - It is impossible to follow sudden water changes. River } \\
\text { network may not be available everywhere suitable for all } \\
\text { destinations. }\end{array}$ \\
\hline Opportunities & Threats \\
\hline $\begin{array}{l}\text { - It provides opportunity to improve waterway transportation. } \\
\text { - It provides new recreation areas. } \\
\text { - It provides increased recreational activities based on water. }\end{array}$ & $\begin{array}{l}\text { - There are threats of flooding and overflow. } \\
\text { - There are threats of landslide and dent. } \\
\text { - The roads cause destructions on natural areas. } \\
\text { - It is a threat to the migration routes of the birds. The fauna } \\
\text { in shores and environment of water are impressed. } \\
\text { - The exhaust gas, fuel and oil pollute the waters. } \\
\text { - Transportation noise impress the fauna. } \\
\text { - Noise, dust, gas, and density prevent to use the water shores } \\
\text { for recreational aims. } \\
\text { - It affects on existing recreational areas in water shores } \\
\text { - It divides and impresses agricultural estate and fertile soils. }\end{array}$ \\
\hline
\end{tabular}


In result of evaluation, there are positive and negative sides of the roads that follow water shores. The positive side consists of mostly economic reasons and enjoy of travelling. And the negative side is mostly ecologic reasons like negative effect on the nature and intensive increasing of recreation areas.

\section{Conclusions}

Settlements set near waterfront or underground water source because of agriculture and farming (Tunçdilek 1985; Tapur 2009; Demir 2003; Selim 2011; Keleş et al. 2012). Important cities have water elements near them. At the same time river, lake or sea are as the hunting-ground for settlers (Tunçdilek 1988). Water elements are natural barriers because of difficulty to pass them. Therefore they offer thesecurity in settlements (Şahinalp 2006). Stream, lake, and sea are important parts of landscape. They have effects on the aspects of environment, e. g. geology, history, culture, and biology (Yildirım et al. 2013). They have an effect on transportation, too. The water elements are used both to transportation and as a guide to roads (Değerliyurt 2014). Turkey has some important settlements of the world in point of the water. Turkey has 26 basins and they give form to settlements in Turkey (Selim 2011).

According to the results; rivers, lakes, and seas are important factors in determining the transit routes of the roads. The water elements use the routes for which geographic conditions are the most suitable and this serves as a guide for the transport network. Because these itineraries are relatively flatter, more convenient and also micro climatic areas with more views due to the proximity to the water element. The very same fact became the reason of the road transit root as well, considering the geographical conditions, using the shortest possible transitions and straight lines with mostly parallel and close to the water element. When the results are evaluated, it is seen that the road networks generally follow the water networks. The road networks knowingly or unknowingly built in parallel to water's edge. This situation increases scenery, transportation comfort and travel pleasure. In the same time, it also derives a profit in economic. Additionally, provincial and district centers have also been established to be particularly close to the water elements due to its landscape and economic factors, the appropriate geographic and climatic conditions.

\section{Acknowledgements}

I thank Prof. Dr. Şevket Metin Kara for the language editing and I thank Assist. Prof. Dr. Yeliz Kaşko Arıcı for the statistical analysis. I value the constructive comments of reviewers and editors as they significantly improved the quality of the final manuscript.

\section{References}

Atabeyoğlu, Ö. 2004. The evaluation of the gardens of the institution and public houses in the respect of landscape architecture: Master Thesis. Atatürk University Graduate School of Natural and Applied Science, Erzurum.

Atabeyoğlu, Ö.; Bulut, Y. 2007. Evaluation of outdoor quality efficiency of public institutions with scoring method, The Journal of Süleyman Demirel University Faculty of Forestry A(1): 92-106.

Atabeyoğlu, Ö.; Turgut, H.; Yeşil, P.; Yılmaz, H. 2012. Evaluation of alterations on historical urban structure of Erzurum with fractal analysis method, The Journal of Süleyman Demirel University Faculty of Forestry 13: 162-171.

Blanton, P.; Marcus, W. A. 2009. Railroads, roads and lateral disconnection in the river landscapes of the continental United States, Geomorphology 112: 212-227.

http://dx.doi.org/10.1016/j.geomorph.2009.06.008

Değerliyurt, M. 2014. Factors affecting use of space in cities. Urban Studies I. Ankara: Detay Publication.

Demir, E. 2003. The contribution of the Southeastern Anatolian Project to the domestic economy and its effect on the settlements areas, Journal of Gazi Education Faculty 23(3): 189-205.

DSİ. 2016. Soil, water resource. General directorate of state hydraulic works [online], [cited 03 April 2016]. Available from Internet: http://www.dsi.gov.tr/toprak-ve-su-kaynaklari

Eigenbrod, F.; Hecnar, S. J.; Fahrig, L. 2007. Accessible habitat: an improved measure of the effects of habitat loss and roads on wildlife populations, Landscape Ecology 23: 159-168. http://dx.doi.org/10.1007/s10980-007-9174-7

E-Interior. 2016. The Counties of Turkey. Ministry of Interior [online], [cited 18 December 2012]. Available from Internet: https://www.e-icisleri.gov.tr/Anasayfa/MulkiIdariBolumleri. aspx

Fu, W.; Liu, S.; Dong, S. 2010. Landscape pattern changes under the disturbance of road networks, Procedia Environmental Sciences 2: 859-867.

http://dx.doi.org/10.1016/j.proenv.2010.10.097

Geneletti, D. 2003. Biodiversity impact assessment of roads: an approach based one ecosystem rarity, Environmental Impact Assessment Review 23: 343-365. http://dx.doi.org/10.1016/S0195-9255(02)00099-9

Hawbaker, T. J.; Radeloff, V. C. 2004. Roads and landscape pattern in Northern Wisconsin based on a comparison of four road data sources, Conservation Biology 18(5): 1233-1244. http://dx.doi.org/10.1111/j.1523-1739.2004.00231.x

HGK. 2013a. Administrative map of Turkey, General Command of Mapping [online], [cited 20 January 2013]. Available from Internet: http://www.hgk.msb.gov.tr/tematik-haritalar

HGK. 2013b. Physical Map of Turkey. General Command of Mapping [online], [cited 20 January 2013]. Available from Internet: http://www.hgk.msb.gov.tr/tematik-haritalar

Jenelius, E.; Mattsson, L. G. 2015. Road network vulnerability analysis: Conceptualization, implementation and application, Computers, Environment and Urban Systems 49: 136-147. http://dx.doi.org/10.1016/j.compenvurbsys.2014.02.003

Kaya, H. S. 2003. Evaluating richness of urban space by using chaos theory and fraktal geometry: Master's Thesis. Istanbul Technique University, Graduate School Of Natural And Applied Sciences, Istanbul, Turkey. 
Keleş, R.; Hamamcı, C.; Çoban, A. 2012. Environmental policy. Ankara: İmge Bookstore.

Liu, S.; Dong, Y.; Deng, L.; Liu, Q.; Zhao, H.; Dong, S. 2014. Forest fragmentation and landscape connectivity change associated with road network extension and city expansion: a case study in the Lancang River Valley, Ecological Indicators 36: 160-168. http://dx.doi.org/10.1016/j.ecolind.2013.07.018

Liu, S. L.; Cui, B. S.; Dong, S. K.; Yang, Z. F.; Yang, M.; Holt, K. 2008. Evaluating the influence of road networks on landscape and regional ecological risk - a case study in Lancang River Valley of Southwest China, Ecological Engineering 34(2): 9199. http://dx.doi.org/10.1016/j.ecoleng.2008.07.006

Patarasuk, R. 2013. Road network connectivity and land-cover dynamics in Lop Buri province, Thailand, Journal of Transport Geography 28: 111-123.

http://dx.doi.org/10.1016/j.jtrangeo.2012.11.011

Selim, S. 2011. The potential effects of ecosystem integrity on human source activities on the river valley: a case of Çağlayan River, Journal of Natural and Applied Sciences 15(2): 94-101.
Seppala, M. 1999. Geomorphological aspects of road construction in a cold environment, Finland, Geomorphology 31: 6591. http://dx.doi.org/10.1016/S0169-555X(99)00073-2

Şahinalp, M. S. 2006. The factors effecting on establishment of Şanluurfa City, Journal of Geographical Sciences 4(1): 105-127.

Topur, T. 2009. Effect on first settlements of ancient Konya Lake, Blacksea Research 6(23): 99-115.

Tian, G.; Wu, J. 2015. Comparing urbanization patterns in Guangzhou of China and Phoenix of the USA: The influences of roads and rivers, Ecological Indicators 52: 23-30. http://dx.doi.org/10.1016/j.ecolind.2014.11.024

Tunçdilek, N. 1985. Relief forms and land uses in Turkey. İstanbul: İstanbul University Publications, No. 3279.

Tunçdilek, N. 1988. Population dynamics in the world. İstanbul: İstanbul University Publications, No: 3501.

Yıldırım, E.; Yılmaz, T.; Benliay, A. 2013. Important of stream ecology on landscape planning, Turkish Journal of Scientific Reviews 6(1): 51-54.

Ömer ATABEYOĞLU. PhD, Assist. Prof. Dr in Department of Landscape Architecture, Faculty of Agriculture, Ordu University in Ordu/Turkey. Research interests: landscape design, urban design, urban planning, historical places. Published 41 scientific paper, made 19 scientific presentations in conferences. 